\title{
COATING OF 1.4404 STAINLESS STEEL BY A COMBINATION OF BRAZING AND NITRIDING
}

\author{
Ali Al-Azzawi , Peter Baumli \\ Institute of Physical Metallurgy, Metalforming and Nanotechnology, \\ University of Miskolc, Miskolc, Hungary
}

Received 10.02.2018.

Accepted 16.10.2018.

\begin{abstract}
In the current research, surface hardening of 1.4404 stainless steel was investigated. A hard Ni-containing coating was prepared by brazing at $1150{ }^{\circ} \mathrm{C}$ using a $\mathrm{Ni}$ foil with Si powder. The hardness behavior was increased by nitriding as well. The nitriding experiments were performed at low and high temperatures $\left(460\right.$ and $\left.640{ }^{\circ} \mathrm{C}\right)$ for a different period $(3$ and $6 \mathrm{~h})$. The microstructure and material properties were characterized using scanning electron microscope (SEM), energy dispersive spectroscopy (EDS) and Micro Vickers hardness testing. Results show that the hard phase and the binding Ni foil were well distributed into the hard layer. The hard coating material was composed of a Si-phases and Ni-containing compound dispersion.

After the nitriding, the hardness of the samples was increased with increasing the nitriding time and temperature and increasing the brazing time. The $10 \mathrm{~min}$ brazing and $6 \mathrm{~h}$ nitriding at $640^{\circ} \mathrm{C}$ resulted in $32 \%$ higher hardness than the non-nitride sample.

Strong metallurgical bonding is formed between the stainless steel substrate and the coating layer, as well as between the binding Ni foil and the hard phase; because of the mutual diffusion of alloying elements, the hardness of this hard coating was 2 to 3 times higher than the initial hardness of steel substrate.

Keywords: stainless steel 1.4404; nickel alloy; silicon; brazing; nitriding; phase composition.

\section{Introduction}

Brazing is an exciting joining process which can be used for joining metals with metals or metals with non-metals with third molten metal and for coating of metals. Using this technique, it is possible to improve surface properties such as surface hardness and the resistance to wear [1], corrosion and oxidation, and to take advantage of longer service life and the consequent reduction of total cost of replacing the tools. There are many
\end{abstract}

*Corresponding author: Ali Al-Azzawi,al_azzawwi@uomisan.edu.iq 
techniques for composite coatings such as laser technologies, but the sample can become deformed due to mechanical stresses because of the rapid cooling of the melted part and the non-uniform temperature. In order to avoid such high mechanical stresses in the sample, there is a growing interest among researchers in composite coating preparation by brazing. High vacuum or an inert gas atmosphere is used in the brazing process, and the whole sample is heated up. In this method, the mechanical stresses in the sample can be avoided or reduced [2].

Several different types of braze fillers can be used for coating of steels. Among these, $\mathrm{Ni}$ and $\mathrm{Cu}$ base fillers are commonly used [3-5]. The experimental conditions such as temperature, the composition of the atmosphere, holding time and substrate composition play the critical roles in determining the spreading characteristics and the interfacial morphology of the final interfaces. Ni-alloy active filler metals have attracted more attention due to their mechanical performance and wettability. The Ni-based solid solution shows stable properties and plays a critical role in influencing the mechanical properties and wettability of the filler metals in the brazing process [6]. Using highresolution electron microscopy, a unique class of thin, disordered films has been identified at grain boundaries. Grain boundary wetting of a solid metal by another liquid metal is described as a phenomenon that occurs in the absence of any external stress and results in the replacement of the initial grain boundary by a liquid film with the creation of two solid/liquid interfaces [7]. The characteristics of the joint metal will differ from those of the metals joined, but the compatibility should be the maximum obtainable. Compatibility means that there must be a sufficiently close affinity between the brazing filler metal and both of the metals of the joint at the brazing temperature and that the bond will possess some similarity of physical and mechanical properties [8] of brazed metals.

High wettability of ceramic materials by molten metal fillers is a principal requirement for successful brazing. The wettability contact angle should range from $\sim 5^{\circ}$ to $\sim 20^{\circ}$. Low values of the contact angle mean high adhesion of fillers to solid phase [9]. Liquid phase bonding process, including brazing and transient liquid phase bonding (TLPB) technique, is one of the most promising techniques for joining ceramics to metals [10-13].

Gas nitriding is a thermochemical surface treatment in which nitrogen is transferred from an ammonia atmosphere into the surface of steels at temperatures within the ferrite and carbide phase region [14]. After nitriding, a compound layer and an underlying diffusion zone (i.e., case) form near the surface of the steel. The compound layer, also known as the white layer, consists predominantly of $\varepsilon-\mathrm{Fe}_{2-3}(\mathrm{C}, \mathrm{N})$ and $\gamma-$ $\mathrm{Fe}_{4} \mathrm{~N}$ phases and can greatly improve the wear and corrosion resistance. The hardened diffusion zone, which is composed of the interstitial solid solution of nitrogen dissolved in the ferrite lattice and nitride and carbonitrides precipitation for the alloy steels containing the nitrides forming elements, is responsible for the considerable enhancement of the fatigue endurance. Furthermore, being a low-temperature process, nitriding minimizes the distortion and deformation of the heat treated parts. Therefore, nitriding is an important surface treatment for ferritic steels [15].

The main goals of this work are to investigate the behavior of a nickel foil on the surface of steel 1.4404, the effect of the holding time of brazing and the effect of nitriding parameters (temperature, time, and the nitriding atmosphere) to reach high hardness coating on the surface and to evaluate the coating results. For brazing experiments, the 
following materials were used: steel 1.4404 as a substrate, silicon powder (particle size $\leq$ $63 \mu \mathrm{m})$ and a nickel-alloy foil layer $(0.25 \mathrm{~mm}$ thickness $)$.

\section{Experimental procedure}

In current work, the active nickel foil which has a chemical composition as shown in Table 1, with a layer from Si powder (particles size $<63 \mu \mathrm{m}$ ) brazing has conducted on the 1.4404 stainless steel substrate which has hardness $182-197 \mathrm{HV}_{0.05}$, and chemical composition as shown in Table 2 . The surface of the stainless-steel substrate $(10 \times 15 \mathrm{~mm})$ and the nickel alloy foil $(10 \times 15 \mathrm{~mm})$ was cleaned by sodium hydroxide $(\mathrm{NaOH})$ solution which has concentration $10 \mathrm{wt} . \%)$, for $5 \mathrm{~min}$, after that washed with distilled water, then ethanol $\left(\mathrm{C}_{2} \mathrm{H}_{5} \mathrm{OH}\right)$ and then dried. After that, the steel was covered with silicon powder, and the nickel foil was placed on the top of a silicon powder layer. This sample was placed in a resistance heating vacuum furnace with an effective chamber size of $\varnothing 20 \times 145 \mathrm{~mm}$, and the chamber was evacuated to the vacuum level of $1.0 \times 10^{-4} \mathrm{mbar}$. The temperature was gradually increased for different time periods until reaching $1100{ }^{\circ} \mathrm{C}$ (the melting point of nickel).

Table 1. The chemical composition of Ni foil.

\begin{tabular}{cccccccc}
\hline Elements & $\mathrm{Al}$ & $\mathrm{Si}$ & $\mathrm{Cr}$ & $\mathrm{Mn}$ & $\mathrm{Fe}$ & $\mathrm{Ni}$ & $\mathrm{Mo}$ \\
\hline wt.\% & 0.13 & 6.61 & 17.33 & 0.11 & 0.90 & 69.72 & 5.20 \\
\hline
\end{tabular}

Table 2. The chemical composition of 1.4404 steel* .

\begin{tabular}{|c|c|c|c|c|c|c|c|c|c|}
\hline Elements & $\mathrm{C}$ & $\mathrm{Si}$ & $\mathrm{Mn}$ & $\mathrm{P}$ & $\mathrm{S}$ & $\mathrm{Cr}$ & Mo & $\mathrm{Ni}$ & $\mathrm{N}$ \\
\hline wt.\% & 0.03 & 1.0 & 2.0 & 0.045 & 0.015 & 17.5 & 2.25 & 11.5 & 0.11 \\
\hline
\end{tabular}

The samples are kept at $1100{ }^{\circ} \mathrm{C}$ for $1 \mathrm{~min}$ in the first experiment and $10 \mathrm{~min}$ in another experiment. The furnace temperature was then reduced gradually for different time periods until reaching $300{ }^{\circ} \mathrm{C}$. When the furnace temperature reached $300{ }^{\circ} \mathrm{C}$ the assistant vacuum device was switched off after $30 \mathrm{~min}$, the central vacuum device was switched off, and the argon gas was released into the furnace to protect the sample from oxidation. When the furnace chamber reached the room temperature, the sample was removed from the furnace. 


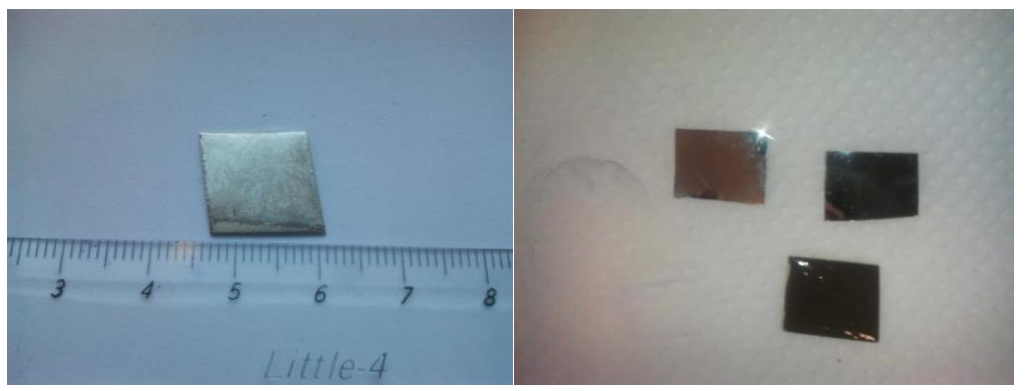

Fig. 1. Brazed samples.

After completing the coating process as shown in Figure 1, the thermal treatment of the samples is performed by the nitriding process.

In the gas nitriding process the brazed samples were placed in the furnace and heated up (the nitriding temperatures were $460{ }^{\circ} \mathrm{C}$ and $640{ }^{\circ} \mathrm{C}$. The holding time of the nitriding were 6 and $3 \mathrm{~h}$. For nitriding, we used ammonia (flow rate of ammonia was: $200 \mathrm{~L} / \mathrm{h}$ ) with $\mathrm{N}_{2}$ and $\mathrm{CO}_{2}$ gas (flow rate of $\mathrm{N}_{2}$ was $200 \mathrm{~L} / \mathrm{h}$ and $15 \mathrm{~L} / \mathrm{h}$ in the case of $\mathrm{CO}_{2}$.

\section{Methods and techniques}

Images of the surface morphology and cross section of the coatings were captured and studied by Scanning Electron Microscopy (ZEISS EVO MA 10 and HITACHI S4800 models). The element's content was analyzed using energy dispersive spectroscopy (EDS).

Microhardness measurements on the cross sections of the coatings were carried out using a Mitutoyo MVK H1 hardness tester, applying a load of $5 \mathrm{~g}$, with a holding time of $10 \mathrm{~s}$.

\section{Results and discussion}

The cross-section of the brazed samples has been investigated by SEM and the EDS methods. One of the SEM images is shown in Figure 2, and the compositions of the phases are collected in Table 3.

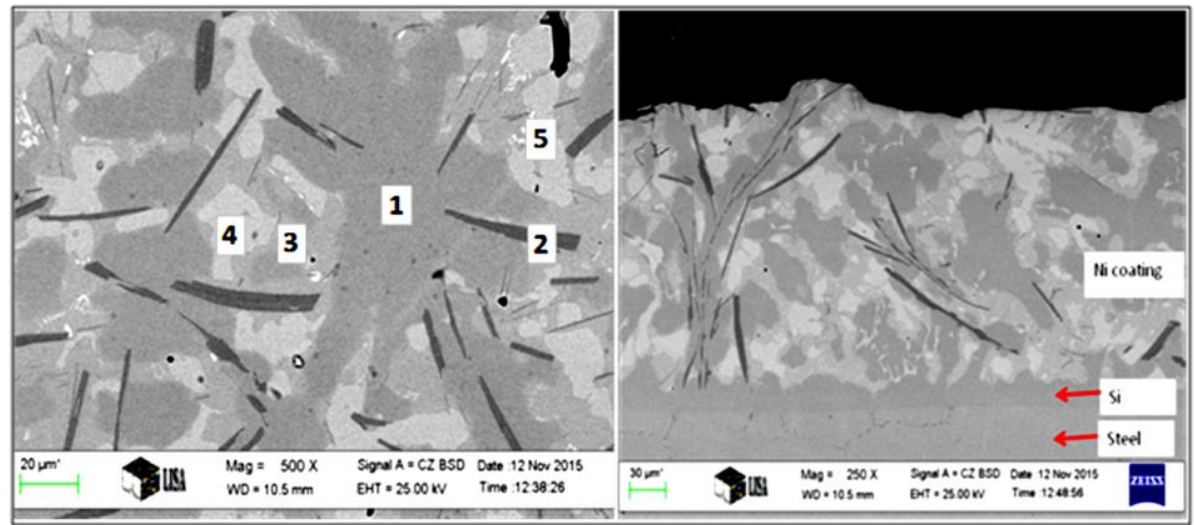

Fig. 2. SEM images of the cross-section of the brazed steel. 
Table 3. Weight and the atomic ratio of points 1, 2, 3, 4 and 5 of the SEM images in Fig. 2.

\begin{tabular}{lccccc}
\hline Materials & $\begin{array}{c}\text { Point 1 } \\
\text { wt\% }\end{array}$ & $\begin{array}{c}\text { Point 2 } \\
\text { wt\% }\end{array}$ & $\begin{array}{c}\text { Point 3 } \\
\text { wt\% }\end{array}$ & $\begin{array}{c}\text { Point 4 } \\
\text { wt\% }\end{array}$ & $\begin{array}{c}\text { Point 5 } \\
\text { wt\% }\end{array}$ \\
\hline $\mathrm{Si}$ & 19.2 & 1.1 & 20 & 13.7 & 14.5 \\
$\mathrm{Mo}$ & 0.8 & 7.2 & 0.8 & 12.6 & 31.4 \\
$\mathrm{Cr}$ & 5.9 & 66.1 & 5.9 & 16 & 9.3 \\
$\mathrm{Fe}$ & 39.5 & 23,1 & 19.7 & 28.6 & 16.4 \\
$\mathrm{Ni}$ & 32.5 & 2.5 & 54.5 & 29.2 & 28.6 \\
\hline
\end{tabular}

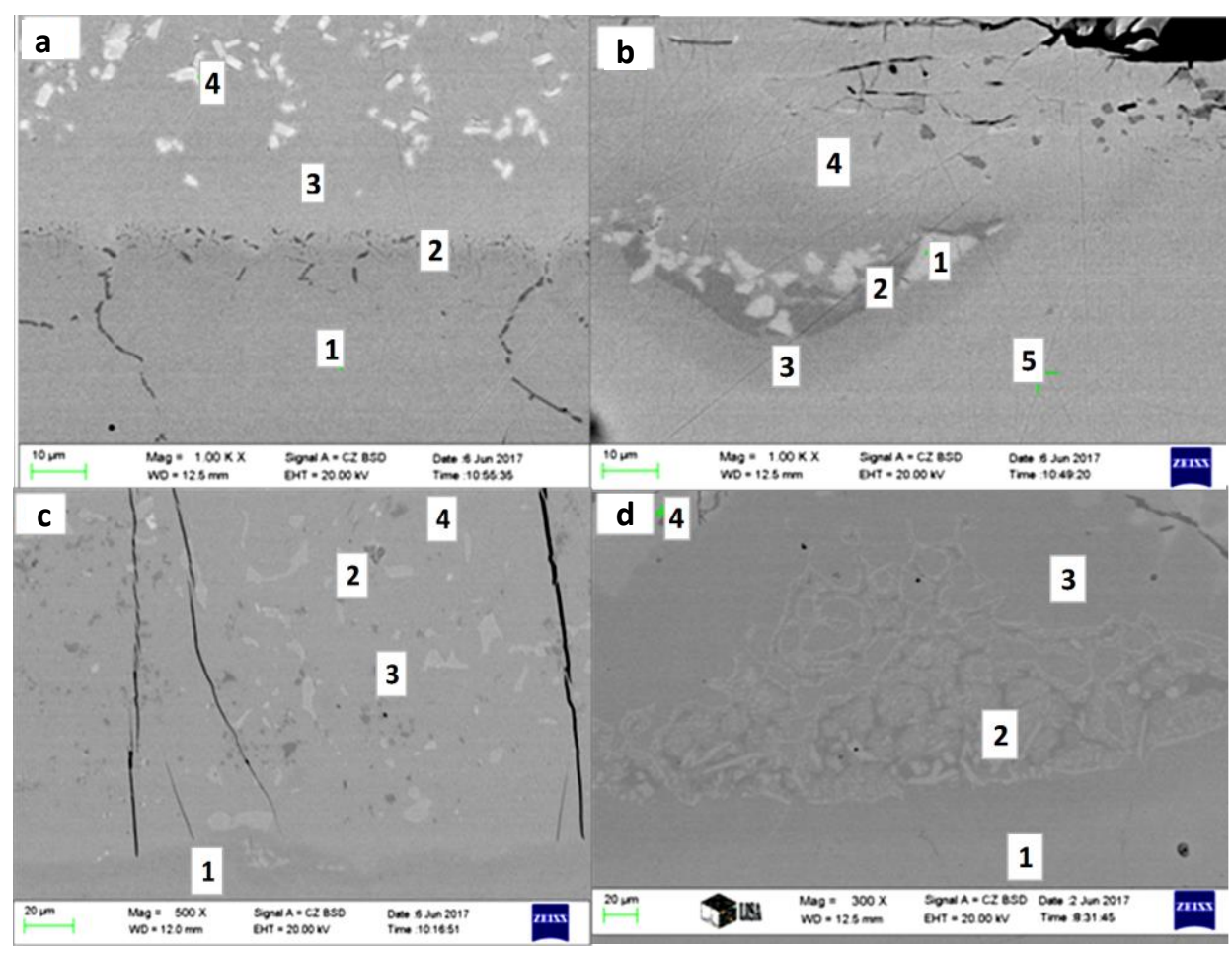

Fig. 3. SEM images of the cross-section of the brazed-nitrided steel at $460^{\circ} \mathrm{C}$.

(a) Brazing holding time 1min, nitriding $3 \mathrm{~h}$

(b) Brazing holding time 10min, nitriding $3 \mathrm{~h}$

(c) Brazing holding time $1 \mathrm{~min}$, nitriding $6 \mathrm{~h}$

(d) Brazing is holding time 10 min, nitriding $6 h$. 


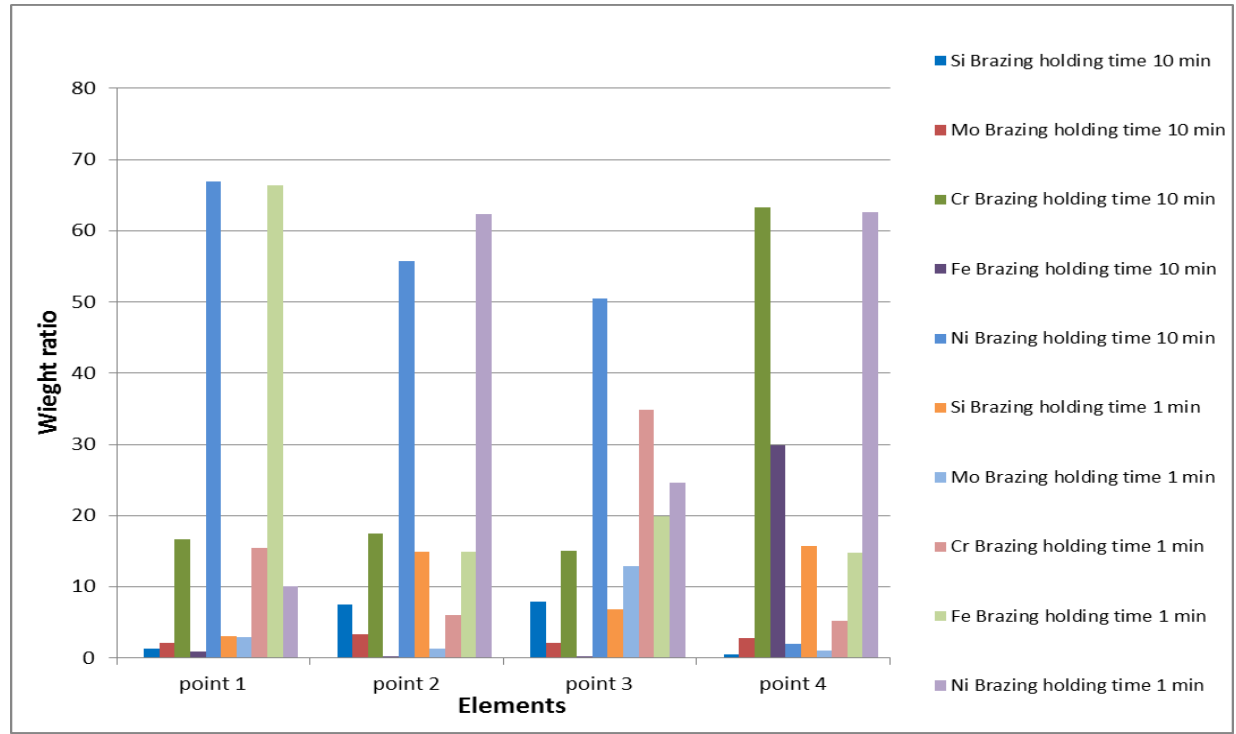

Fig. 4 Weight ratio of elements of images $(a)$ and $(b)$ in Fig. 3, nitriding temperature $460{ }^{\circ} \mathrm{C}$, holding time $3 \mathrm{~h}$.

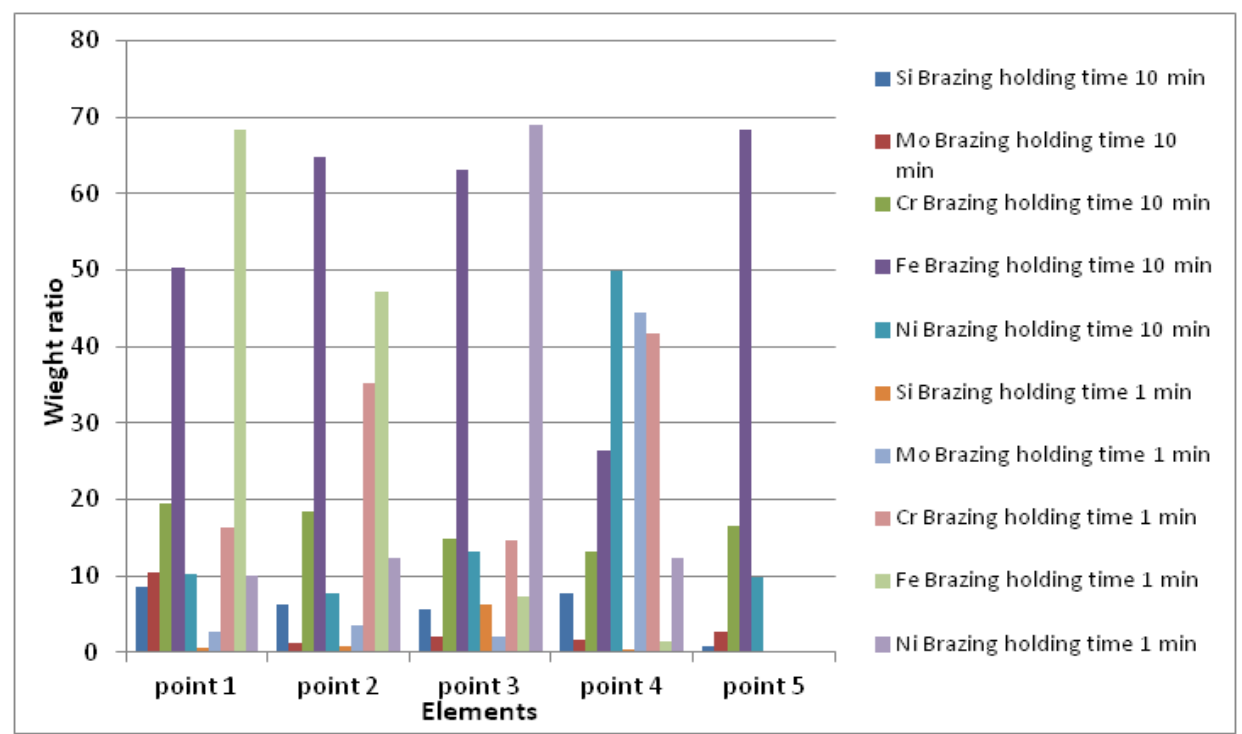

Fig. 5. The weight ratio of elements of images $(c)$ and $(d)$ in Fig. 3, nitriding temperature $460{ }^{\circ} \mathrm{C}$, holding time $6 \mathrm{~h}$. 


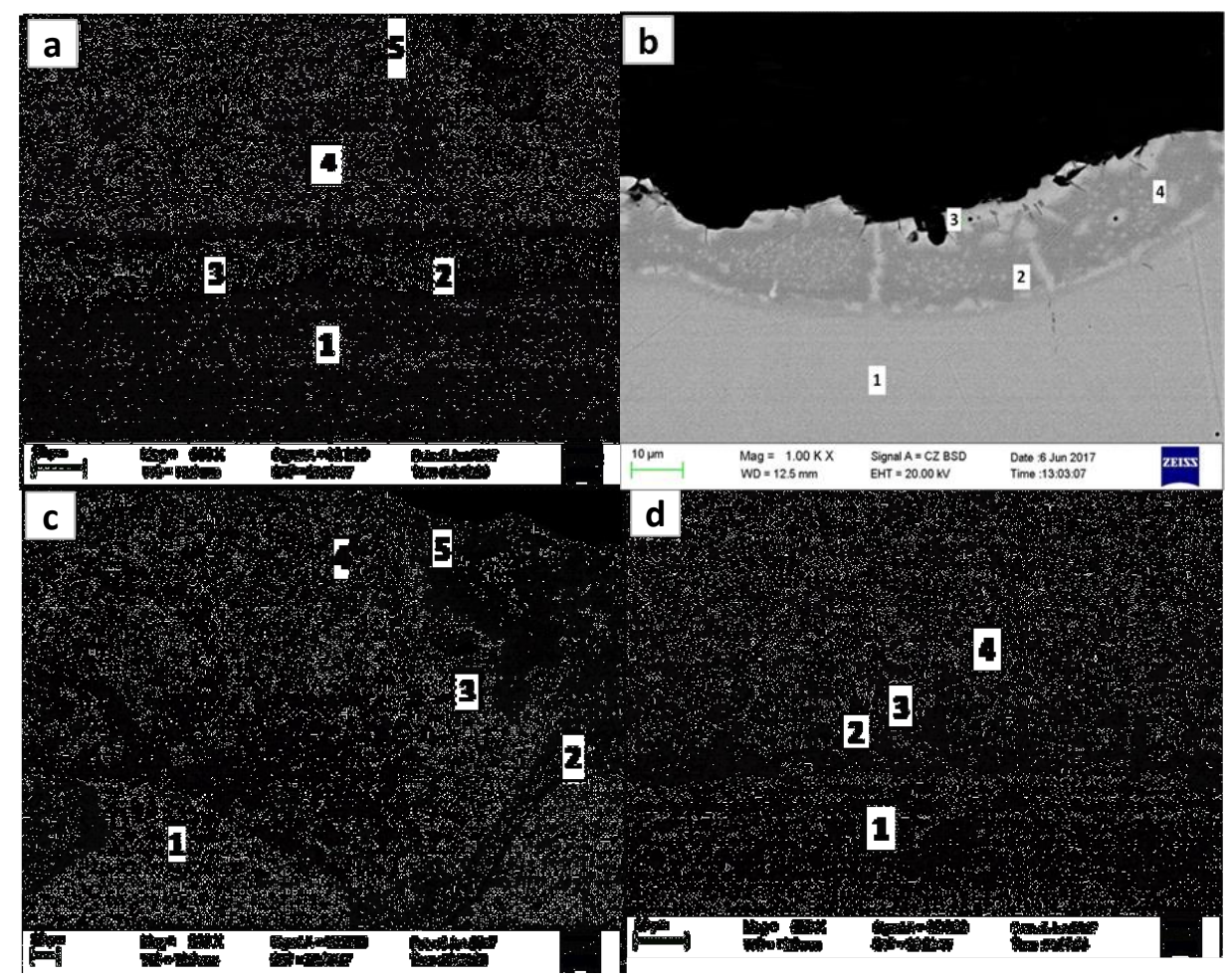

Fig. 6. SEM images of the cross-section of the brazed-nitrided steel at $640{ }^{\circ} \mathrm{C}$.

(a) Brazing holding time 1min, nitriding $3 \mathrm{~h}$,

(b) Brazing holding time 10min, nitriding $3 \mathrm{~h}$,

(c) Brazing holding time 1min, nitriding $6 \mathrm{~h}$,

(d) Brazing holding time 10min, nitriding $6 \mathrm{~h}$.

From SEM images in Figure 2, it can be seen that the Si powder dissolved in the $\mathrm{Ni}$ brazer and formed a coherent layer between the steel and the Ni foil (Figure 2). This high Si-containing layer dissolved $\mathrm{Ni}$ and Fe from the steel substrate as well. $\mathrm{The} \mathrm{Cr}$ in the melted Ni brazer can form $\mathrm{Cr}-\mathrm{Fe}$ needles, which crossed the brazed coating. The SEM images in Figures 3 and 6 display the effect of brazing and nitriding parameters (holding time and temperature) for the dissolution and diffusion of the particles of compounds of $\mathrm{Ni}$ foil and Si powder in the steel matrix. The more homogeneous microstructure can be observed at $10 \mathrm{~min}$ of brazing holding time in comparison with $1 \mathrm{~min}$ of brazing holding time. This means that the longer brazing holding time assists the elements of the brazing component to dissolve and diffuse into the brazing layer and form a strong adhesion layer with the steel matrix. 


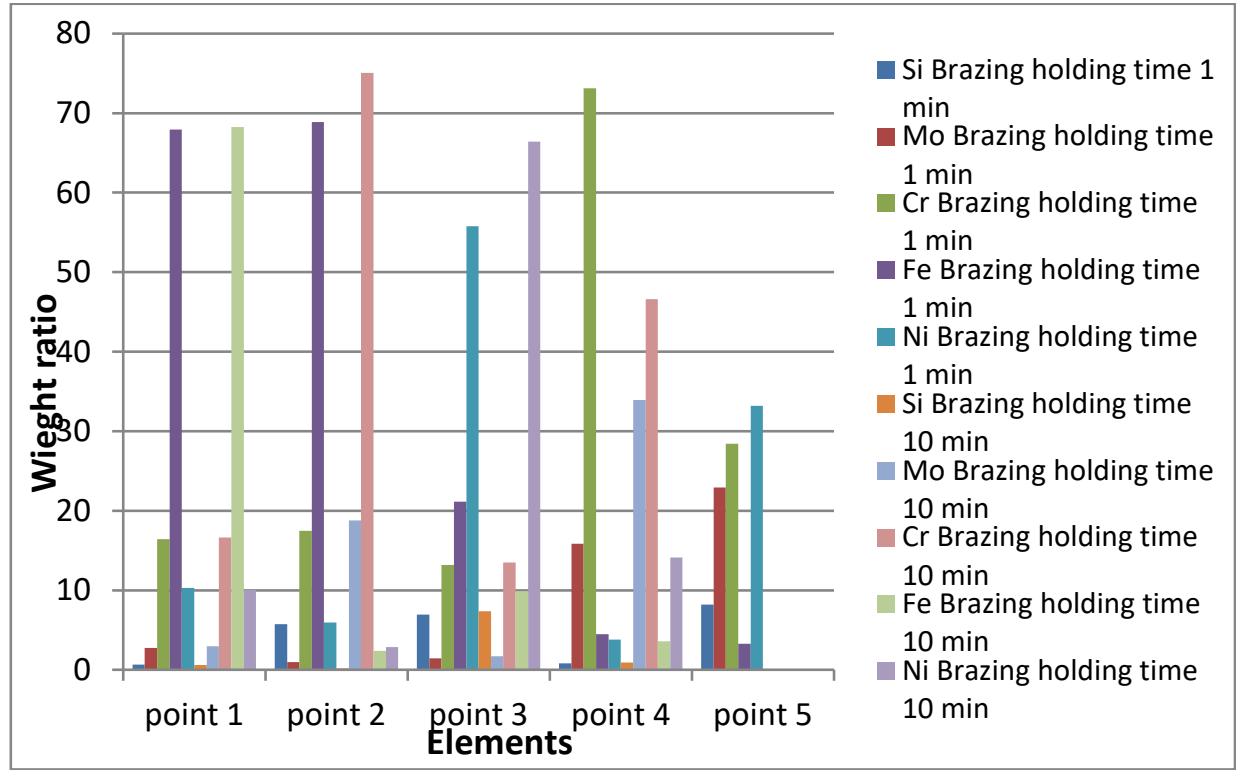

Fig. 7. The weight ratio of elements of images $(a)$ and $(b)$ in Fig. 6, nitriding temperature $640^{\circ} \mathrm{C}$, holding time $3 \mathrm{~h}$.

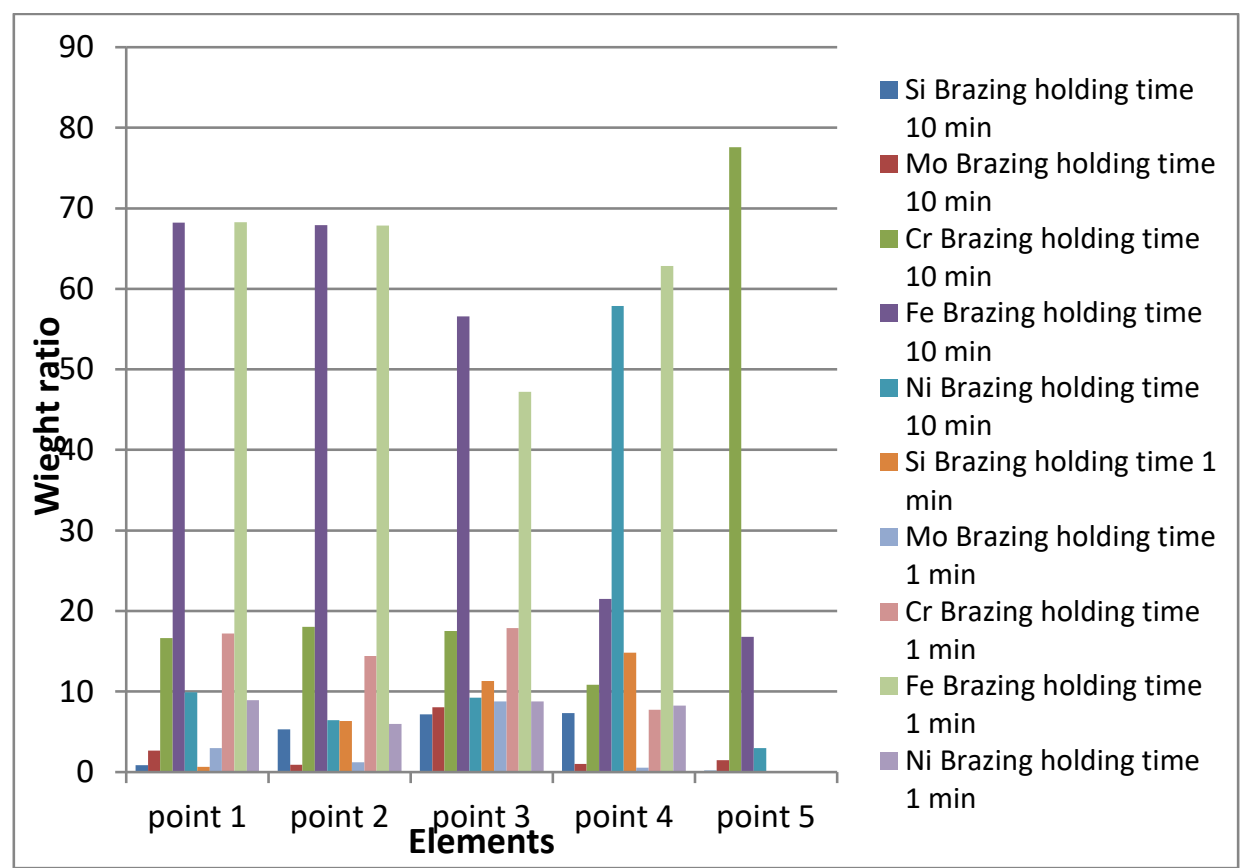

Fig. 8. The weight ratio of elements of images $(c)$ and $(d)$ in Fig. 6, nitriding temperature $640^{\circ} \mathrm{C}$, holding time $6 \mathrm{~h}$. 


\section{Hardness investigation}

Results for the micro Vickers hardness test done on the samples after the brazingnitriding process are shown in Figure 9.

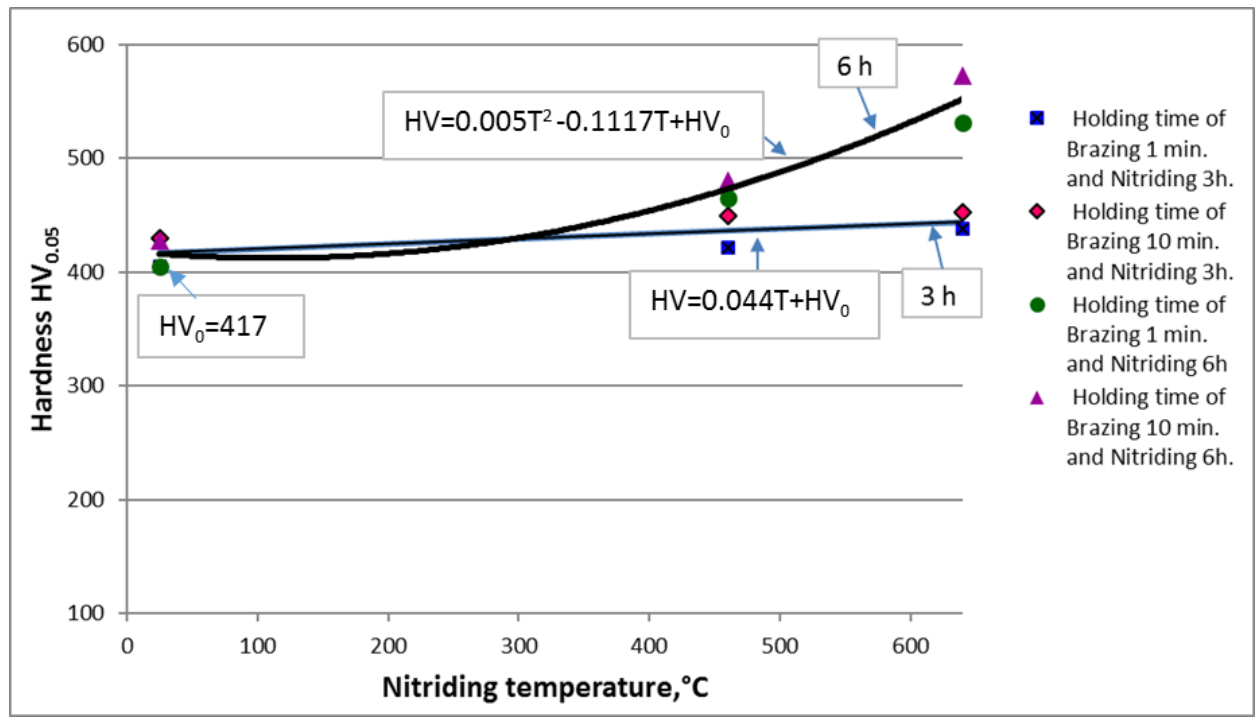

Fig. 9. Hardness diagram of steel 1.4404 as a function of nitriding temperature.

From the results of the hardness investigation, as shown in Figure 9., we can observe that the hardness of nitrided samples with $10 \mathrm{~min}$ of holding time for brazing is higher than that for samples with a 1 min of holding time, in both cases of nitriding holding time ( 3 or 6 hours).

There is no significant effect of the nitriding temperature on the hardness of the brazed sample at $3 \mathrm{~h}$ nitriding. However, after $6 \mathrm{~h}$ nitriding the hardness changes according to the $\mathrm{HV}=0.005 \mathrm{~T}^{2}-0.1117 \mathrm{~T}+\mathrm{HV}_{0}$ equation (where the $\mathrm{HV}_{0}$ means hardness of the brazed coating without nitriding).

Therefore, nitriding can contribute to increasing the hardness of the obtained coating. Thus, with the brazing-nitriding process, it was possible to achieve hardness values 2-3 times higher than without the brazed-nitrided layer.

\section{Conclusion}

The initial hardness of the 1.4404 steel was $182-197 \mathrm{HV}_{0.05}$, which increased to 475-513 $\mathrm{HV}_{0.05}$, after the brazing-nitriding treatment. During this process, the Si powder partially dissolves in the $\mathrm{Ni}$ foil, which melts at $1100^{\circ} \mathrm{C}$, and forms a coherent layer between the steel and the melted $\mathrm{Ni}$ layer. The phase in the coating formed a compound with $\mathrm{Fe}$, which was dissolved from the substrate, whereas layers of $\mathrm{Fe}_{4} \mathrm{~N}-\mathrm{Fe}$ and $\mathrm{Fe}_{4} \mathrm{~N}$ $\mathrm{Fe}_{3} \mathrm{~N}$ were formed above the brazed layer. The hardness values of the layers depend on the parameters of the brazing and nitriding processes (holding time and temperature). The optimal values were obtained at longer holding time, and higher temperature, the hardness of the Ni-Si brazed-nitrided layer above stainless steel 1.4404 is 2-3 times higher than the initial steel hardness. 


\section{Acknowledgment}

The authors are thankful to Mrs. Agnes Balogh Csurilla for the hardness measurements, Mrs, Napsugár Nyári Bodnár for sample preparation, and Dr. Dániel Koncz-Horváth for SEM investigation and Dr. Zsolt Veres for nitriding experiments. The research work presented is based on the results achieved within the GINOP2.3.2-15-2016-00027 "Sustainable operation of the workshop of excellence for the research and development of crystalline and amorphous nanostructured materials" project implemented in the framework of the Szechenyi 2020 program. The realization of this project is supported by the European Union.

\section{References}

[1] Xia Zhou, Guohui Qu, Jiyang Zhou, Xiwen Wang: Materials Processing Technology, 168 (2005) 280-285.

[2] Al-Azzawi Ali, P. Baumli: Materials Science and Engineering, University of Miskolc HU, 40 (2015) 26-32.

[3] American Welding Society (AWS) C3 Committee on Brazing and Soldering: Supersedes Brazing Handbook, 4th edition, Miami, USA, 1991, 86.

[4] M. Ali, K.M. Knowles, P.M. Mallinson, J.A. Fernie: Acta Mater, 103 (2016) 859869.

[5] D.M. Jacobson, G. Humpston: Principles of Brazing, 1st edition, ASM International Ohio, USA, 2005, 32.

[6] D. Liu, H.W. Niu, Y.H. Zhou, X.G. Song, D.Y. Tang, J.C. Feng: Materials and Design, 87 (2015) 42-48.

[7] K. Wolski, V. Laporte: Materials Science and Engineering, A 495 (2008) 138-146.

[8] H.R. Brooker, E.V. Beatson: Industrial Brazing, Welding and metal fabrication, Newnes-Butterworths, London, 2nd., 1975, 263.

[9] Y.V. Naidich, V.S. Zhuravlev, I.I. Gab, B.D. Kostyuk, V.P. Krasovskyy, A.A. Adamovskyy, N.Yu. Taranets: European Ceramic Society, 28 (2008) 717-728

[10] M.L. Muoloa, F. Valenza, F. Monteverde, N. Sobczak: J Acta Materialia, 57 (2009) 356-364.

[11] M. L. Muolo, D. Passerone: Materials Science, 41 (2006) 5088-5098.

[12] Y.V. Naidich, V.S. Zhuravlev, I.I. Gab, B.D. Kostyuk, V.P. Krasovskyy, A.A. Adamovskyy, N.Yu. Taranets: European Ceramic Society, 28 (2008) 717-728.

[13] V. Bougiouri, R. Voytovych, O. Dezellus, N. Eustathopoulos: Materials Science, 42 (2016) 2016-2023.

[14] N. Saunders, A. P. Miodownik: CALPHAD Calculation of Phase Diagrams: A Comprehensive Guide Pergamon, Guildford, UK, 1st edition, 1998, 478.

[15] C. Kim, M. Dayananda: Metallurgical and Materials Transactions, A 15 (1984) 649659.

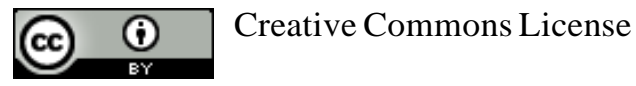

This work is licensed under a Creative Commons Attribution 4.0 International License. 